$\begin{array}{cc}\text { ACADEMIA ROMÂNĂ } & \text { Rev. Roum. Chim., } \\ \text { Revue Roumaine de Chimie } & \text { 2019, 64(6), 535-546 } \\ \text { http://web.icf.ro/rrch/ } & \text { Doi: } 10.33224 / \text { rrch.2019.64.6.10 }\end{array}$

\title{
DESIGN AND SYNTHESIS OF NEW ANTI-AMYLOID NAP-BASED/LIKE PEPTIDES
}

\author{
Ancuța-Veronica LUPAESCU, ${ }^{a}$ Cătălina-Ionica CIOBANU,, a,b Ionel HUMELNICU, ${ }^{a}$ \\ Brînduşa Alina PETRE, ${ }^{\mathrm{a}, \mathrm{c},{ }^{*}}$ Manuela MURARIU ${ }^{\mathrm{d}}$ and Gabi DROCHIOIU ${ }^{\mathrm{a}, *}$ \\ ${ }^{a}$ Faculty of Chemistry, Al. I. Cuza University, 11 Carol I, Iași-700506, Roumania \\ ${ }^{\mathrm{b}}$ Research Department, Faculty of Chemistry, “A1. I. Cuza” University, 11 Carol I, Iaşi-700506, Roumania \\ ${ }^{c}$ Center for Fundamental Research and Experimental Development in Translation Medicine - TRANSCEND, \\ Regional Institute of Oncology, 2-4 General Henri Mathias Berthelot, Iaşi-700483, Roumania \\ ${ }^{d}$ Petru Poni Institute of Macromolecular Chemistry, 41a Ghica Voda Alee, Iaşi-700487, Roumania
}

Alzheimer's disease (AD) is promoted by the formation of insoluble aggregates at the synapse level such as extracellular deposition of $\beta$-amyloid $(\mathrm{A} \beta)$ peptides and intracellular accumulation of tau protein leading to disruption of synaptic activity and loss of synapses. Since the interaction of $A \beta$ peptide with metal ions is known to promote peptides aggregation, compounds which exhibit chelating properties can be used to prevent the interaction of the amyloid peptide with metal ions. Therefore, we have synthesized four new peptides sequences derived from the anti-amyloid NAP peptide $\left({ }^{1} \mathrm{NAPVSIPQ}^{8}\right)$. We focused our study on the sequence of three amino acids ${ }^{5} \mathrm{SIP}^{7}$, known as active center of the native octapeptide, where we replaced the serine residue with glycine, alanine, histidine and tyrosine. The purpose of our peptide design is a better understanding of disaggregating properties of the NAP peptide and its role as potent inhibitor against $A \beta$ peptide aggregation. The newly synthesized peptides were purified by HPLC and characterized by MALDI-ToF mass spectrometry and Fourier transform infrared spectroscopy (FT-IR). Both HPLC analytical chromatograms and MALDI-ToF spectra confirmed the synthesis of the desired peptides and their high purity, while the FT-IR analysis showed that peptide conformation varies from one peptide to another.

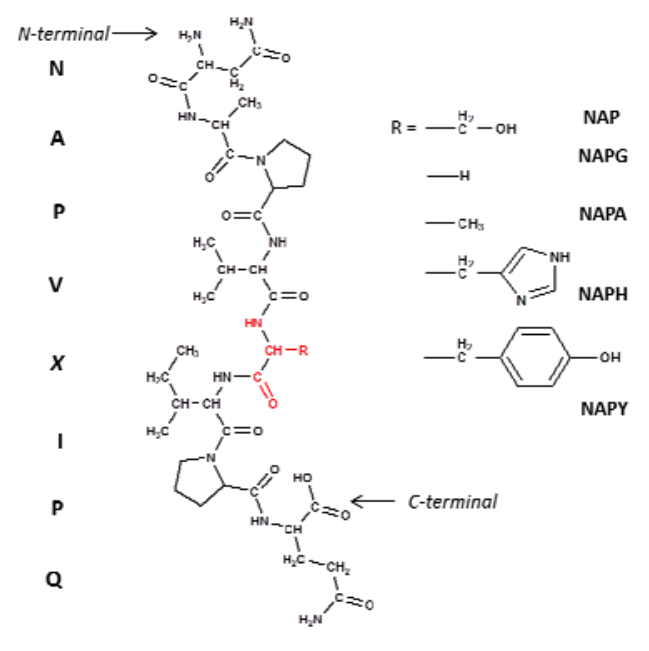

\section{INTRODUCTION}

During recent years, an increase in the field of peptide biochemical research was noticed. This tremendous progression has led to the development of peptides and proteins as therapeutic agents. ${ }^{1}$ In order to grow their specificity towards target molecules, the new peptide compounds may require sequence modifications or insertion of nonnatural amino acids. ${ }^{2,3}$ Peptide synthesis is considered to be a viable alternative for obtaining novel designed therapeutic agents. Fmoc solid phase peptide synthesis (SPPS) is generally the method of choice for the synthesis of modified peptides. ${ }^{4-8}$ This method allows the researcher to use the imagination and creativity to generate new peptides capable of giving new biological activity. ${ }^{9,10}$ For example, the characteristic of membrane passing, one of the main problems in therapeutic efficiency, may be accomplished by the cell-penetrating peptides. ${ }^{11}$ Generally, SPPS involves the use of a resin as support for peptide chain assembling. The desired sequence is produced from the $\mathrm{C}$-terminus, which is attached to

\footnotetext{
* Corresponding authors: gabidr@uaic.ro and brindusa.petre@uaic.ro
} 
a solid support, to the N-terminus through repetitive cycles of amino acids additions. Moreover, this method requires the use of "temporary" and "permanent" protecting groups which are stable to the reaction conditions and can be removed with the help of piperidine base or trifluoroacetic acid (TFA), respectively, in order to ensure the addition of one amino acid per step. ${ }^{1,12}$

Neuroprotective peptides have been widely studied for their significant prevention and improvement of the conditions of degenerative diseases. Neurodegenerative disorders such as Alzheimer, Parkinson and Creutzfeldt-Jacob diseases are associated with protein misfolding. ${ }^{13}$ Conformational changes are thought to be the prime mechanism of amyloid plaque formation in the neurodegenerative diseases by changing the morphology of the entire brain. ${ }^{14}$

NAP $\left({ }^{1} \mathrm{NAPVSIPQ}^{8}\right.$ ) is a small active fragment of the Activity-Dependent Neuroprotective Protein, ADNP (354-361), which provides neuroprotection at very low concentrations and arises from studies of vasoactive intestinal peptides. ${ }^{15}$ The octapeptide protects cells by promoting the reorganization of the microtubular network and facilitates neurite outgrowth. ${ }^{16}$ Besides, NAP promotes the dissolution of amyloid plaques and prevents $A \beta$ aggregation, one of the main pathological issue in AD ${ }^{17,18}$ Its bioavailability and extend neuroprotection made this peptide a pharmaceutical candidate for both intranasal and intravenous routes. ${ }^{19}$ NAP derivatives peptides are of scientific and clinical interest during aging, because they may reduce tauopathy and provide neuro and cognitive protection of the brain. In this regard, the D-NAP active peptide, ${ }^{20}$ obtained by replacing all $\mathrm{L}$-amino acids with D-amino acids, and IsoNAP peptide, ${ }^{21}$ which contains alpha-aminoisobutyric acid instead of the proline residues to enhance its $\beta$-sheet breaker, have been shown to reduce protein misfolding. Moreover, $\mathrm{Oz}$ et al. and Gozes et al. showed that NAPVSIPQ interacts with the microtubule end-binding protein (EB1) through SIP domain (Ser-Ile-Pro). ${ }^{22,23}$ Studies involving the interaction between NAP modified peptides and metal ions such as iron(III) and cooper(II) showed the formation of $\mathrm{Fe}^{2+}$-peptide complexes and $\mathrm{Cu}^{+}-$ peptide complexes providing new information about the mechanism of interaction with $\mathrm{A} \beta$ aggregates. $^{7,8}$

In the present study, we have synthesized four NAP-like peptides via solid-phase peptide synthesis (SPPS). The goal of this work was also to investigate the conformational differences among the five peptides and to examine potential mechanisms based on structure-properties relationship that underlie such differences. Such peptides could be of particular interest in investigating the relationship between metal ions and peptides or proteins involved in neurodegenerative diseases. Here, the newly synthesized peptides were investigated by mass spectrometry using a MALDI-ToF mass spectrometer, whereas their conformation was studied by FT-IR spectroscopy. In addition, the properties and spatial distribution of the five peptides were theoretically anticipated with the help of the GPMAW software and Chem3D Ultra software.

\section{RESULTS AND DISSCUSION}

\section{Peptide synthesis and characterization}

The characteristics of native NAP peptide synthesized in our study are presented in Table 1. In principle, the syntheses targeted the ${ }^{5} \mathrm{SIP}^{7}$ (SerIle-Pro) sequence of native peptide NAP considered by some researchers as its active center. ${ }^{22}$ Fig. 1 shows the amino acid sequence that forms the basic skeletons of the NAP peptides. As observed there, all the peptides contain similar structures except for the fifth amino acid (highlighted with red). More exactly, by replacing serine with glycine $\left({ }^{5} \mathrm{~S} \rightarrow \mathrm{G}\right)$ a new peptide with the structure $\mathrm{H}_{2} \mathrm{~N}$-(Asn-Ala-Pro-Val-Gly-Ile-Pro-Gln)$\mathrm{COOH}$ was obtained (abbreviated NAPG). In the case of NAPA peptide, the synthesis was carried out on using alanine instead of serine $\left({ }^{5} \mathrm{~S} \rightarrow \mathrm{A}\right)$ and thus, the $\mathrm{H}_{2} \mathrm{~N}$-(Asn-Ala-Pro-Val-Ala-Ile-Pro-Gln)$\mathrm{COOH}$ peptide was synthesized. Similar to the previous cases, other two peptides (NAPH: $\mathrm{H}_{2} \mathrm{~N}$ (Asn-Ala-Pro-Val-His-Ile-Pro-Gln)-COOH and NAPY: $\quad \mathrm{H}_{2} \mathrm{~N}-($ Asn-Ala-Pro-Val-Tyr-Ile-Pro-Gln)$\mathrm{COOH})$ containing histidine $\left({ }^{5} \mathrm{~S} \rightarrow \mathrm{H}\right)$ and tyrosine $\left({ }^{5} \mathrm{~S} \rightarrow \mathrm{Y}\right)$ as substitutes for the serine amino acid were obtained.

The synthesis and purification of peptides by RP-HPLC chromatography were performed according to the method described in the experimental section. Since each peptide presents a specific hydrophobicity as determined by its structure, they eluted from the C18-analitical column as major peaks with specific retention times (see Table 1). For example, NAPG $\left({ }^{5} \mathrm{~S} \rightarrow \mathrm{G}\right)$ peptide was the most rapidly eluted at $9.72 \mathrm{~min}$ and $57.5 \%$ B while NAPY $\left({ }^{5} \mathrm{~S} \rightarrow \mathrm{Y}\right)$ peptide was eluted at $10.187 \mathrm{~min}$ corresponding to $62 \%$ solvent B using the same separation conditions. Since the obtained chromatograms contained only the peak characteristic to the pure peptides, no further purification steps were required. 
Table 1

Retention time of peptides analysed by HPLC

\begin{tabular}{lccc}
\hline $\begin{array}{c}\text { Peptide } \\
\text { structure }\end{array}$ & $\begin{array}{c}\text { Peptide } \\
\text { code }\end{array}$ & $\begin{array}{c}\text { Retention time } \\
\text { (min) }\end{array}$ & $\begin{array}{c}\text { Eluent } \\
\text { \% B }\end{array}$ \\
\hline $\mathrm{H}_{2} \mathrm{~N}-($ Asn-Ala-Pro-Val-Ser-Ile-Pro-Gln)-COOH & NAP & 9.777 & 58.0 \\
$\mathrm{H}_{2} \mathrm{~N}-($ Asn-Ala-Pro-Val-Gly-Ile-Pro-Gln)-COOH & NAPG & 9.720 & 57.5 \\
$\mathrm{H}_{2} \mathrm{~N}-($ Asn-Ala-Pro-Val-Ala-Ile-Pro-Gln)-COOH & NAPA & 9.813 & 58.2 \\
$\mathrm{H}_{2} \mathrm{~N}-($ Asn-Ala-Pro-Val-His-Ile-Pro-Gln)-COOH & NAPH & 9.753 & 57.7 \\
$\mathrm{H}_{2} \mathrm{~N}-($ Asn-Ala-Pro-Val-Tyr-Ile-Pro-Gln)-COOH & NAPY & 10.187 & 62.0 \\
\hline
\end{tabular}

The first experimental step after performing the synthesis was to confirm the molecular weight of the resulting peptides. Matrix-assisted laser desorption/ionization time-of-flight mass spectrometry (MALDI-ToF MS) is an efficient method to analyse small proteins and peptides by providing accurate determination of molecular weight measuring ionized molecules. ${ }^{24}$ By comparing the theoretical $\mathrm{m} / \mathrm{z}$ values with the experimental molecular mass values (Table 2), it was possible to confirm the synthesis of the desired peptide sequences.

Figure 2 shows the MALDI -ToF mass spectra of all five NAP peptides here synthesized. The peptide signal corresponding to the molecular ion $[\mathrm{M}+\mathrm{H}]^{+}$was observed only in the NAPH mass spectrum at $\mathrm{m} / \mathrm{z} 875.80$. In the case of all the other NAP peptides, different peaks, which were assigned to the $[\mathrm{M}+\mathrm{H}-16]^{+}$ion, were present in their mass spectra. A proposed mechanism to describe the formation of $[\mathrm{M}+\mathrm{H}-16]^{+}$ion is depicted in Figure 3. The possible nucleophile attack rearrangement that leads to peptide deamination and pyroglutamic acid formation is favoured by the $\mathrm{C}$-terminus glutamine residue. The rule "N-terminal $\mathrm{Q} \rightarrow \mathrm{Q}[-17.027]$ " applies only to $\mathrm{N}$-terminal glutamine peptides. ${ }^{25}$ In addition, the mechanism of deamination is photochemical favoured by the laser light source. This process occurs during the peptide ionization and thus, it can be considered as a post-source decay mechanism.

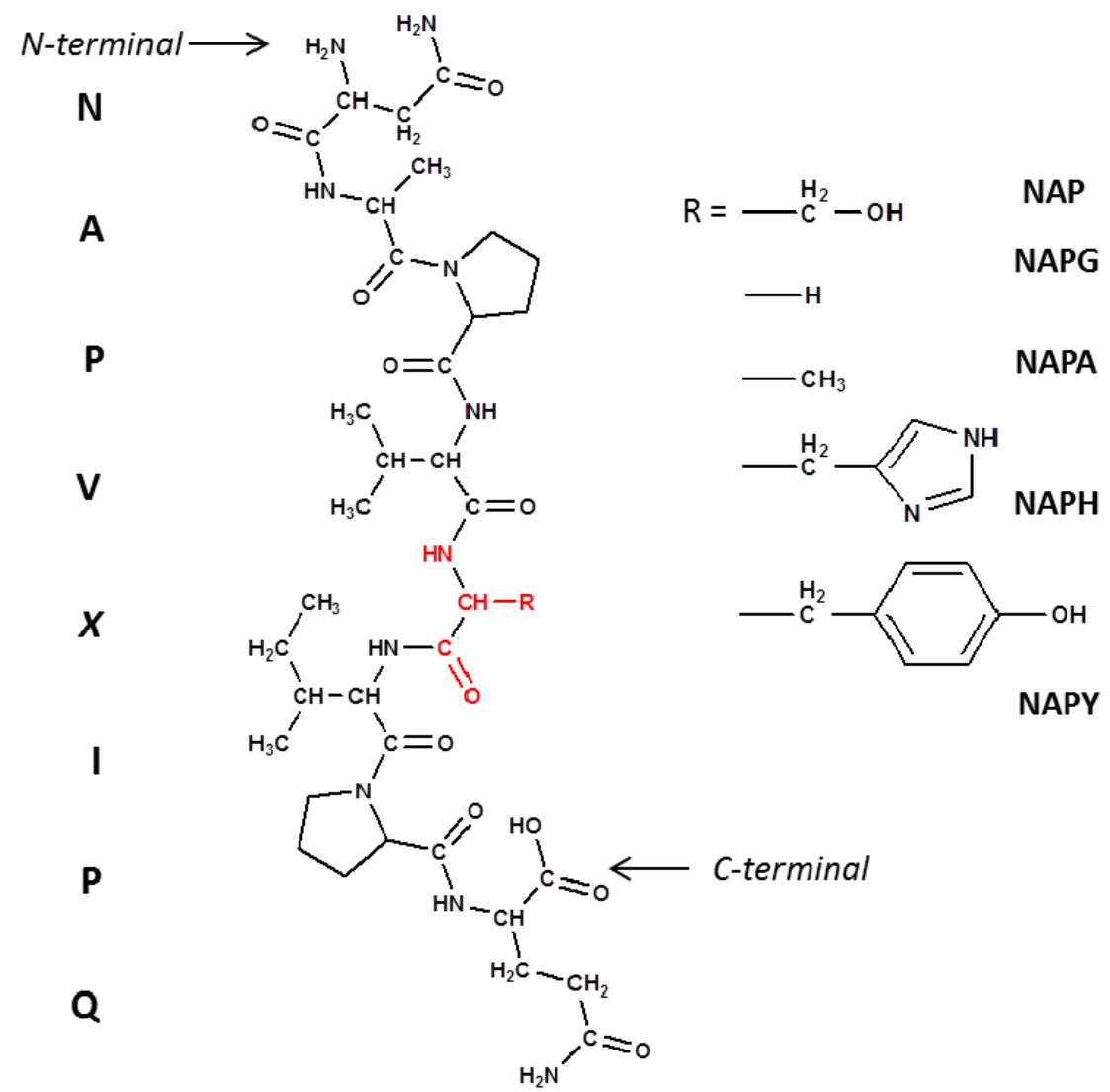

Fig. 1 - General structure of designed peptides derived from NAP. 


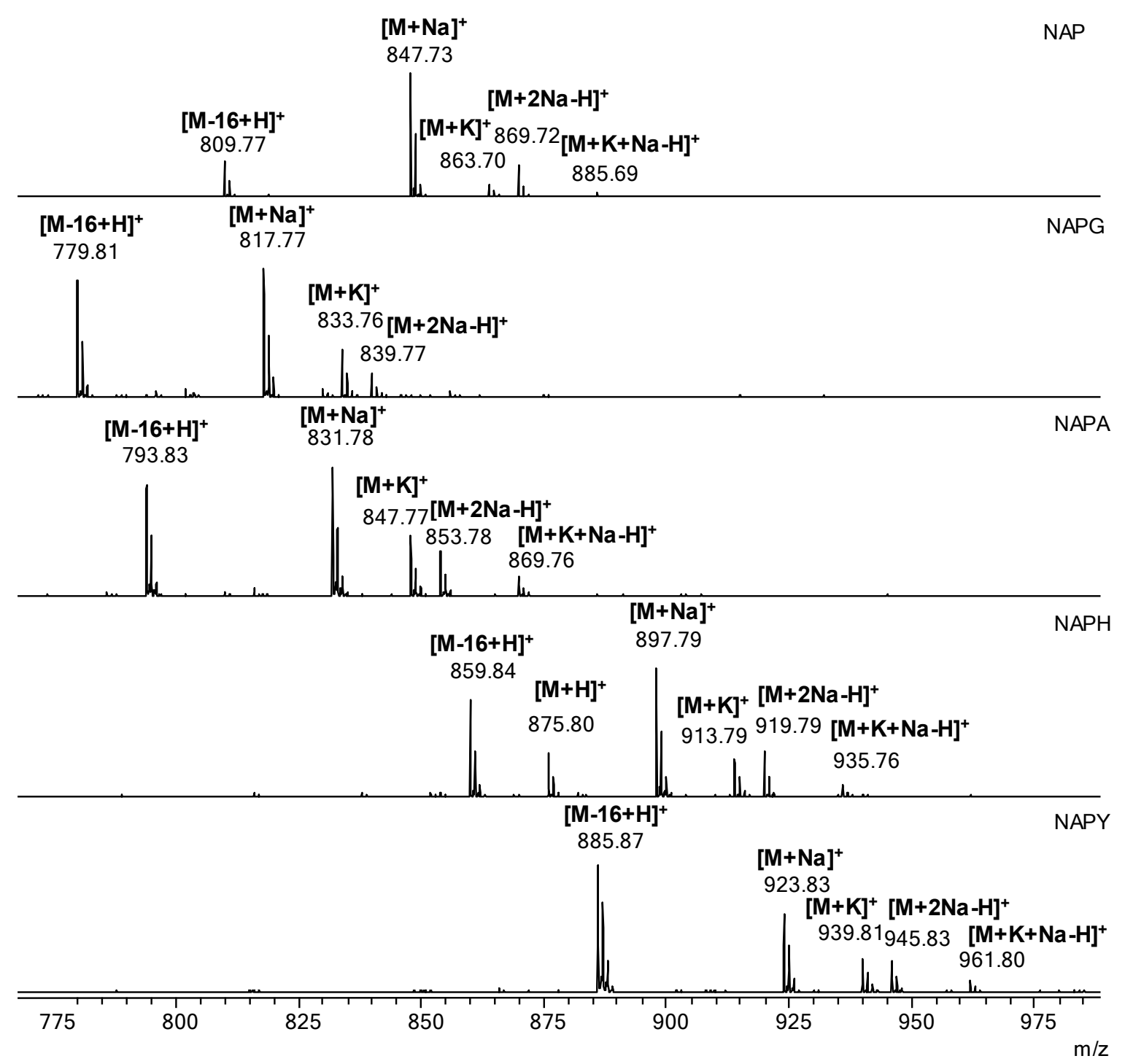

Fig. 2 - MALDI-ToF MS spectra of the newly synthesized NAP-based peptides: NAP native peptide, glycine-mutant NAPG, alanine-mutant NAPA, histidine-mutant NAPH and tyrosine-mutant peptide.

Besides the signal of the intact molecular ion $[\mathrm{M}+\mathrm{H}]^{+}$, and deaminated $[\mathrm{M}-16+\mathrm{H}]^{+}$ion $($at $\mathrm{m} / \mathrm{z}$ 809.77 for NAP; $\mathrm{m} / \mathrm{z} 779.83$ for NAPG; $\mathrm{m} / \mathrm{z}$ 793.83 for NAPA; $\mathrm{m} / \mathrm{z} 859.84$ for NAPH and $\mathrm{m} / \mathrm{z}$ 885.87 for NAPY) two additional peaks, characteristic to $\mathrm{Na}^{+}$and $\mathrm{K}^{+}$adducts were also observed (Fig. 2). Thus, the MALDI-ToF mass spectrum of the peptide NAP showed a characteristic peak at $\mathrm{m} / \mathrm{z} 847.73$, which was assigned to the molecular ion $[\mathrm{M}+\mathrm{Na}]^{+}$, while the characteristic addition of $+39 \mathrm{Da}$ assigned to the potassium adduct was observed at $\mathrm{m} / \mathrm{z}$ 863.70. Other peaks containing the characteristic additions of $+22 \mathrm{Da}$ were attributed to the double sodium adduct $[\mathrm{M}+2 \mathrm{Na}-\mathrm{H}]^{+}(\mathrm{m} / \mathrm{z}$ 869.72) and $[\mathrm{M}+\mathrm{K}+\mathrm{Na}-$ $\mathrm{H}]^{+}$ion $(\mathrm{m} / \mathrm{z} 885.69)$.
The spectrum of NAPG peptide displayed other signals corresponding to sodium adduct $(\mathrm{m} / \mathrm{z}$ $817.78)$ and potassium ion $(\mathrm{m} / \mathrm{z} 833.76)$, together with the peak, characteristic to deaminated peptide $\left([\mathrm{M}-16+\mathrm{H}]^{+}\right.$ion, $\mathrm{m} / \mathrm{z}$ 779.81). Another peak attributed to $[\mathrm{M}+2 \mathrm{Na}-\mathrm{H}]^{+}$ion was observed at $\mathrm{m} / \mathrm{z}$ 839.77. Similarly, the alanine-mutant NAPA peptide displayed signals associated with [M$16+\mathrm{H}]^{+}$ion at $\mathrm{m} / \mathrm{z} 793.83,[\mathrm{M}+\mathrm{Na}]^{+}$ion at $\mathrm{m} / \mathrm{z}$ 831.78 and $[\mathrm{M}+\mathrm{K}]^{+}$ion at $\mathrm{m} / \mathrm{z} 847.77$ in the spectrum. Some signals of low intensity were observed at $\mathrm{m} / \mathrm{z} 853.78$ and $\mathrm{m} / \mathrm{z} 869.76$, being assigned to $[\mathrm{M}+2 \mathrm{Na}-\mathrm{H}]^{+}$ion and $[\mathrm{M}+\mathrm{K}+\mathrm{Na}-\mathrm{H}]^{+}$ ion, respectively. The MALDI-ToF mass spectrum of NAPH peptide contains both signals corresponding to the molecular ion $[\mathrm{M}+\mathrm{H}]^{+}(\mathrm{m} / \mathrm{z}$ 
$875.80)$ and the deamidated $[\mathrm{M}-16+\mathrm{H}]^{+}$ion $(\mathrm{m} / \mathrm{z}$ 859.84). Similar to the other peptides, the most intense signal in the spectrum belongs to the sodium adduct ion $[\mathrm{M}+\mathrm{Na}]^{+}$, found at $\mathrm{m} / \mathrm{z}$ 897.79. Other small signals displayed in the spectrum were attributed to the potassium ion $(\mathrm{m} / \mathrm{z}$ 913.79), $[\mathrm{M}+2 \mathrm{Na}-\mathrm{H}]^{+}$ion $\left(\mathrm{m} / \mathrm{z}\right.$ 919.79) and $[\mathrm{M}+\mathrm{K}+\mathrm{Na}-\mathrm{H}]^{+}$ ion $(\mathrm{m} / \mathrm{z}$ 935.76), respectively. As for NAPY peptide, the recorded mass spectrum presented an intense peak at 885.87, which was assigned to deamidated $[\mathrm{M}-16+\mathrm{H}]^{+}$ion. Other signals, noticed in the spectrum at $\mathrm{m} / \mathrm{z} 923.83, \mathrm{~m} / \mathrm{z} 939.81, \mathrm{~m} / \mathrm{z}$ 945.83 and $\mathrm{m} / \mathrm{z}$ 961.80, were attributed to the sodium and potassium ions.

Table 2 shows the theoretical and experimental values of the main peaks found in the mass spectra. The experimental $\mathrm{m} / \mathrm{z}$ values displayed by the MALDI ToF mass spectrometer were in best agreement with theoretical data obtained using the ChemCalc program.
According to the mechanism described above, the protonated peptide can obey a nucleophile attack that leads to the cyclization of the glutamine residue. The resulted compound is stabilized by removing the ammonium ion. ${ }^{25}$

\section{FT-IR Study}

Infrared spectroscopy is a measurement of wavelength and intensity of the absorption of IR radiation by a sample. ${ }^{27}$ Peptides and proteins contain chains of amino acids linked via amide bonds. The frequencies at which amide bond vibrations occur can be attributed to different secondary structures in which the amide bonds are present. $^{28}$ Thus, modifications in hydrogen bonding among amino acid residues are reflected in the differences appeared on amide bonds vibration. Three major spectral regions (amide I, amide II and amide III) corresponding to $\mathrm{C}=\mathrm{O}, \mathrm{C}-\mathrm{N}$ and $\mathrm{N}-\mathrm{H}$ vibrations characterize structurally the peptide chain. ${ }^{29,30}$

Table 2

Molecular weight of the newly synthesized peptides, as experimentally determined with a MALDI-ToF instrument or calculated with ChemCalc soft ${ }^{26}$

\begin{tabular}{|c|c|c|c|}
\hline Peptide & Molecular Ion & Theoretical (m/z) & Experimental $(\mathbf{m} / \mathbf{z}) *$ \\
\hline $\begin{array}{c}\text { NAP } \\
\left(\mathrm{H}_{2} \mathrm{~N} \text {-NAPVSIPQ-COOH }\right) \\
\mathrm{C}_{36} \mathrm{H}_{60} \mathrm{~N}_{10} \mathrm{O}_{12}\end{array}$ & $\begin{array}{l}{[\mathrm{M}-16+\mathrm{H}]^{+}} \\
{[\mathrm{M}+\mathrm{H}]^{+}} \\
{[\mathrm{M}+\mathrm{Na}]^{+}} \\
{[\mathrm{M}+\mathrm{K}]^{+}}\end{array}$ & $\begin{array}{l}809.42 \\
825.44 \\
847.42 \\
863.40\end{array}$ & $\begin{array}{l}809.77 \\
- \\
847.73 \\
863.70\end{array}$ \\
\hline $\begin{array}{c}\text { NAPG } \\
\left(\mathrm{H}_{2} \mathrm{~N}-\mathrm{NAPVGIPQ-COOH}\right) \\
\mathrm{C}_{35} \mathrm{H}_{58} \mathrm{~N}_{10} \mathrm{O}_{11}\end{array}$ & $\begin{array}{l}{[\mathrm{M}-16+\mathrm{H}]^{+}} \\
{[\mathrm{M}+\mathrm{H}]^{+}} \\
{[\mathrm{M}+\mathrm{Na}]^{+}} \\
{[\mathrm{M}+\mathrm{K}]^{+}}\end{array}$ & $\begin{array}{l}779.42 \\
795.43 \\
817.42 \\
833.39\end{array}$ & $\begin{array}{l}779.83 \\
- \\
817.78 \\
833.77\end{array}$ \\
\hline $\begin{array}{c}\text { NAPA } \\
\left(\mathrm{H}_{2} \mathrm{~N}-\mathrm{NAPVAIPQ}-\mathrm{COOH}\right) \\
\mathrm{C}_{36} \mathrm{H}_{60} \mathrm{~N}_{10} \mathrm{O}_{11}\end{array}$ & $\begin{array}{l}{[\mathrm{M}-16+\mathrm{H}]^{+}} \\
{[\mathrm{M}+\mathrm{H}]^{+}} \\
{[\mathrm{M}+\mathrm{Na}]^{+}} \\
{[\mathrm{M}+\mathrm{K}]^{+}}\end{array}$ & $\begin{array}{l}793.43 \\
809.45 \\
831.43 \\
847.41\end{array}$ & $\begin{array}{l}793.83 \\
- \\
831.78 \\
847.77\end{array}$ \\
\hline $\begin{array}{c}\text { NAPH } \\
\left(\mathrm{H}_{2} \mathrm{~N}-\mathrm{NAPVHIPQ}-\mathrm{COOH}\right) \\
\mathrm{C}_{39} \mathrm{H}_{62} \mathrm{~N}_{12} \mathrm{O}_{11}\end{array}$ & $\begin{array}{l}{[\mathrm{M}-16+\mathrm{H}]^{+}} \\
{[\mathrm{M}+\mathrm{H}]^{+}} \\
{[\mathrm{M}+\mathrm{Na}]^{+}} \\
{[\mathrm{M}+\mathrm{K}]^{+}}\end{array}$ & $\begin{array}{l}859.45 \\
895.47 \\
897.45 \\
913.43\end{array}$ & $\begin{array}{l}859.84 \\
895.80 \\
897.79 \\
913.76\end{array}$ \\
\hline $\begin{array}{c}\text { NAPY } \\
\left(\mathrm{H}_{2} \mathrm{~N}-\mathrm{NAPVYIPQ}-\mathrm{COOH}\right) \\
\mathrm{C}_{42} \mathrm{H}_{64} \mathrm{~N}_{10} \mathrm{O}_{12}\end{array}$ & $\begin{array}{l}{[\mathrm{M}+\mathrm{H}]^{+}} \\
{[\mathrm{M}-16+\mathrm{H}]^{+}} \\
{[\mathrm{M}+\mathrm{Na}]^{+}} \\
{[\mathrm{M}+\mathrm{K}]^{+}}\end{array}$ & $\begin{array}{l}885.46 \\
901.47 \\
923.46 \\
939.43\end{array}$ & $\begin{array}{l}885.87 \\
- \\
923.83 \\
939.81\end{array}$ \\
\hline
\end{tabular}

*(-) not present in the MALDI-ToF mass spectra 


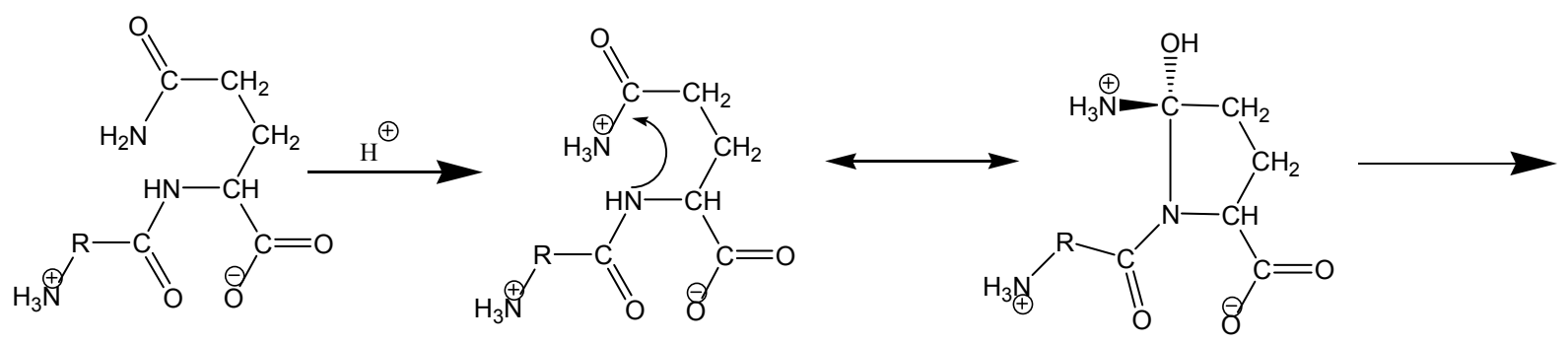

Nucleophilic attack Unstable tetrahedral intermediate

$$
\mathrm{NAP}=824.43 \mathrm{~m} / \mathrm{z} \quad 825.44 \mathrm{~m} / \mathrm{z} \quad 825.44 \mathrm{~m} / \mathrm{z}
$$

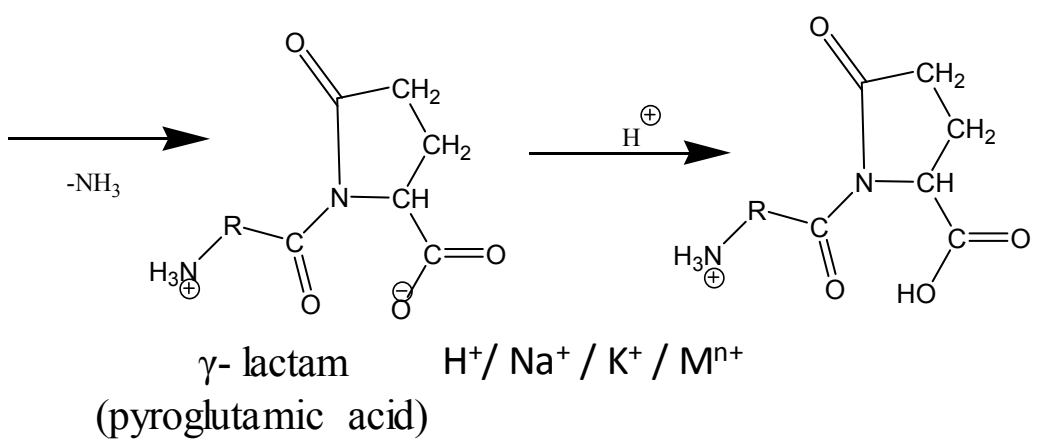

$808.417 \mathrm{~m} / \mathrm{z}$

$809.418 \mathrm{~m} / \mathrm{z}$

Fig. 3 - Proposed mechanism for $[\mathrm{M}+\mathrm{H}-16]^{+}$ion formation.

The IR spectra of NAP peptides presented in Figure 4.a reveals four major peaks between 1800 $\mathrm{cm}^{-1}$ and $1000 \mathrm{~cm}^{-1}$. The similarities presented in the spectra are generated by their peptide chains that differ only through one amino acid. However, differences regarding the bands intensity and peak values can be easily spotted in all the spectra. For example, the peak displayed in the range 1200$1100 \mathrm{~cm}^{-1}$, characteristic for $\mathrm{C}-\mathrm{N}$ stretching and $\mathrm{C}-\mathrm{C}-\mathrm{N}$ bending contains from three to two maxima depending on the type of peptide. Thus, NAP peptide contains three peaks in the band area at $1198 \mathrm{~cm}^{-1}, 1172 \mathrm{~cm}^{-1}$ and $1138 \mathrm{~cm}^{-1}$, while NAPG peptide displays only two peaks at 1161 $\mathrm{cm}^{-1}$ and $1142 \mathrm{~cm}^{-1}$, respectively. Similar peaks were observed in the NAPA peptide spectrum, where another peak can easily be observed at 1165 $\mathrm{cm}^{-1}$, alongside with that maximum at $1198 \mathrm{~cm}^{-1}$. The histidine modified peptide had two peaks at $1162 \mathrm{~cm}^{-1}$ and $1136 \mathrm{~cm}^{-1}$, while the tyrosine peptide was characterized by two maxima at 1197 $\mathrm{cm}^{-1}$ and $1167 \mathrm{~cm}^{-1}$.

The amide I band found between 1700 and $1600 \mathrm{~cm}^{-1}$ is usually the most intense infrared band of the proteins. This signal is primary governed/ mainly caused by the stretching vibrations of the
$\mathrm{C}=\mathrm{O}$ and is directly related to the backbone conformation and the hydrogen bonding pattern. For all peptides, the amide I band was characterized by an intense signal with one or two maxima. Thus, the native NAP peptide displayed one intense signal at $1625 \mathrm{~cm}^{-1}$ corresponding to $\beta$ sheet conformation and another one around 1653 $\mathrm{cm}^{-1}$ characteristic to $\alpha$-helix structure. The glycine-mutant peptide (NAPG) presented two signals: one at $1623 \mathrm{~cm}^{-1}$ and another one at 1655 $\mathrm{cm}^{-1}$ with slight changes compared to the signals of the native peptide. The alanine modified peptide (NAPA) contains only a maximum at $1625 \mathrm{~cm}^{-1}$ without any other at $1653 \mathrm{~cm}^{-1}$. In the case of NAPH and NAPY peptides, the absorption bands displayed values of the maxima shifted to smaller wavenumbers. More exactly, NAPH gave maxima at $1623 \mathrm{~cm}^{-1}$ and $1650 \mathrm{~cm}^{-1}$, while NAPY peptide showed intense signals at $1622 \mathrm{~cm}^{-1}$ and 1646 $\mathrm{cm}^{-1}$. In conclusion, excepting the alanine modified peptide NAPA, which had one intense signal at $1625 \mathrm{~cm}^{-1}$, the other peptides were characterized by two main peaks, one around 1650 $\mathrm{cm}^{-1}$ assigned to $\alpha$-helical structures and another one around $1623 \mathrm{~cm}^{-1}$ corresponding to $\beta$-sheet conformation. 
a)

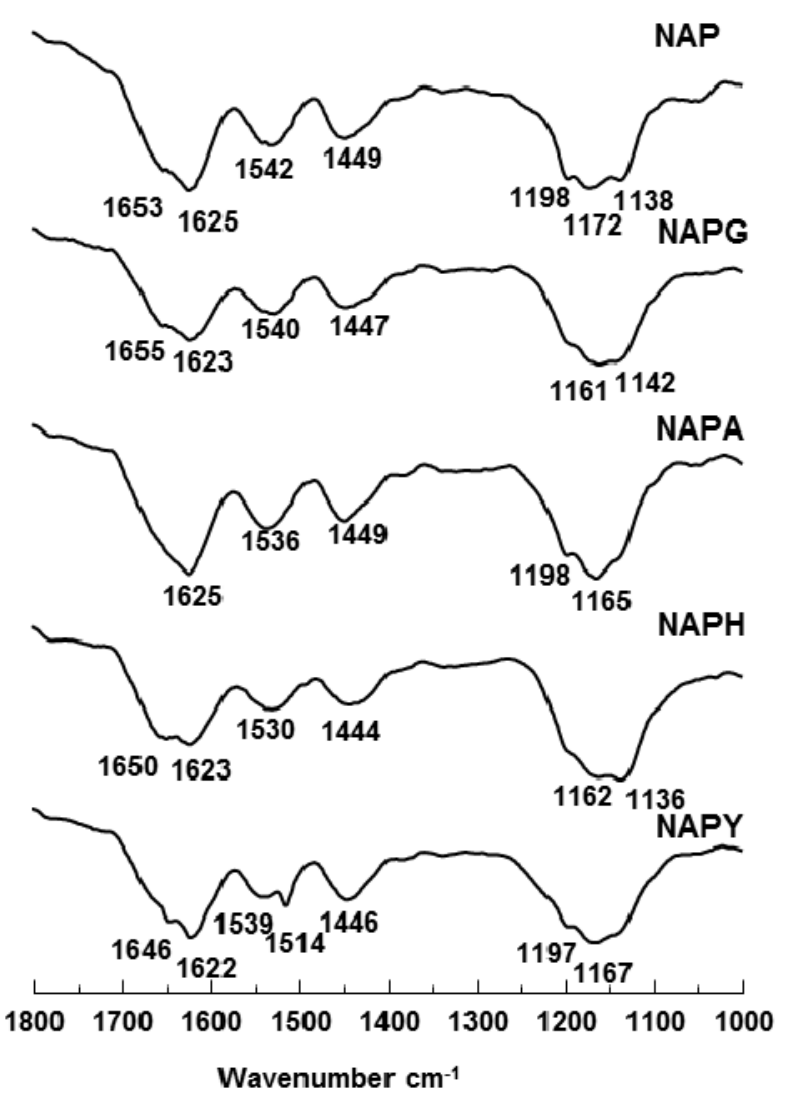

b)

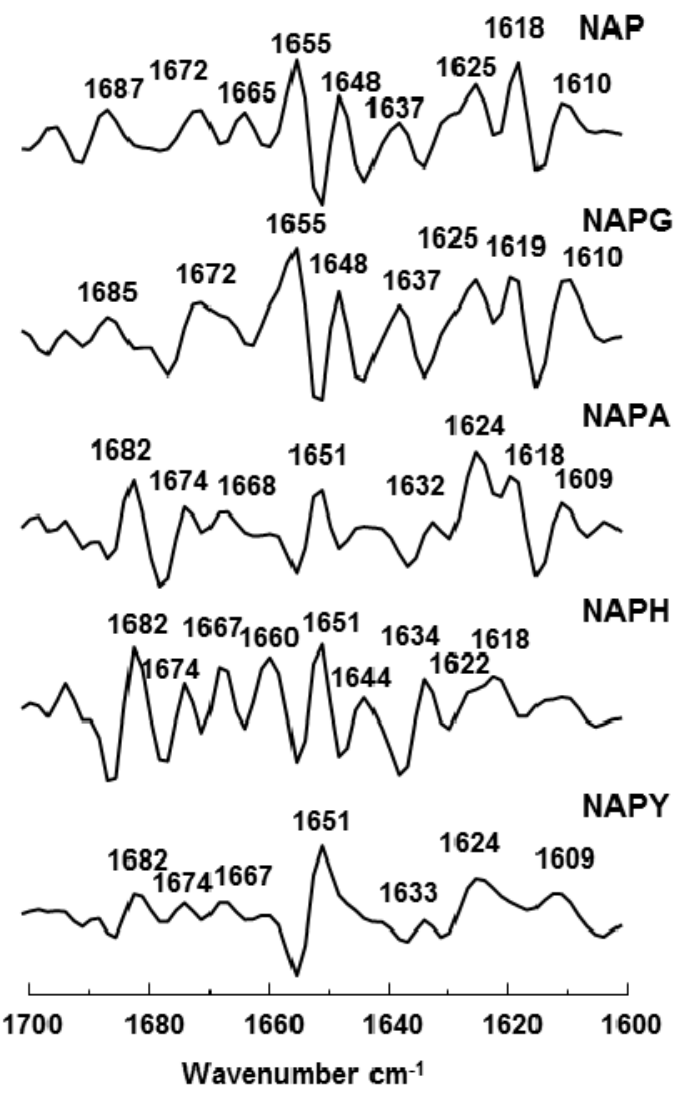

Fig. 4 - FT-IR spectra $\left(1800-1000 \mathrm{~cm}^{-1}\right)$ of the newly synthesized NAP-derived peptides (a) and their amide I band second derivative spectra $\left(1700-1600 \mathrm{~cm}^{-1}\right)(\mathbf{b})$.

The region $1580-1510 \mathrm{~cm}^{-1}$ is characteristic to amide II band and derives mainly from in-plane $\mathrm{N}-\mathrm{H}$ bending and $\mathrm{C}-\mathrm{N}$ stretching. This band is not as sensitive as the amide I and III bands to the variation in secondary structure content. However, its inclusion with amide I band increases the accuracy of the secondary structure prediction in statistical regression methods. The $\alpha$-helix structure was confirmed in the case of NAP and NAPG peptide since the amide II band presented maxima at $1542 \mathrm{~cm}^{-1}$ and $1540 \mathrm{~cm}^{-1}$, respectively. In the case of NAPA and NAPH peptides, the values from $1536 \mathrm{~cm}^{-1}$ and $1530 \mathrm{~cm}^{-1}$ can be attributed to $\beta$-sheet conformation only. As for the NAPY peptide, another signal can be spotted at $1514 \mathrm{~cm}^{-1}$ that partially overlaps the amide II band. However, being short peptides, the conformational studies are rather difficult to carry out.

No signal corresponding to the amide III band (1301-1229 $\mathrm{cm}^{-1}, \mathrm{CN}$ stretching, $\mathrm{NH}$ bending) was observed in the spectra. Around $1444 \mathrm{~cm}^{-1}$, a relative intense band can be detected in all five spectra, which could be assigned to $\mathrm{CH}_{3}$ asymmetric bending vibration. ${ }^{31}$
The analysis of FT-IR spectroscopic data is rather complicated since the absorption peaks often overlap with each other. There are some restrictions encountered in this region that limits the spectral analysis of peptides. For example, the $\mathrm{OH}$ vibrations belonging to liquid water can generate signals in the same region. Thus, from the acquired IR spectra much information about their conformation cannot be used. However, since the FTIR analysis of peptides was performed on solid samples, the restriction generated in this region by the $\mathrm{OH}$ vibrations can be neglected. Furthermore, overlapping peaks can encumber the bands assignment. For example, both $\alpha$-helix and random coils exhibit signal around $1650-1655 \mathrm{~cm}^{-1} .^{29}$ Thereby, we have calculated the second derivative of spectra that brings more details about the IR absorbance of the studied peptides. This method enhances the separation of overlapping peaks and thus, offers a practical and more specific compositional information than the usually absorption spectrum analysis methods. The clearly resolved peaks can be more easily associated to $\alpha$ helix, $\beta$-sheet or $\beta$-turn. 

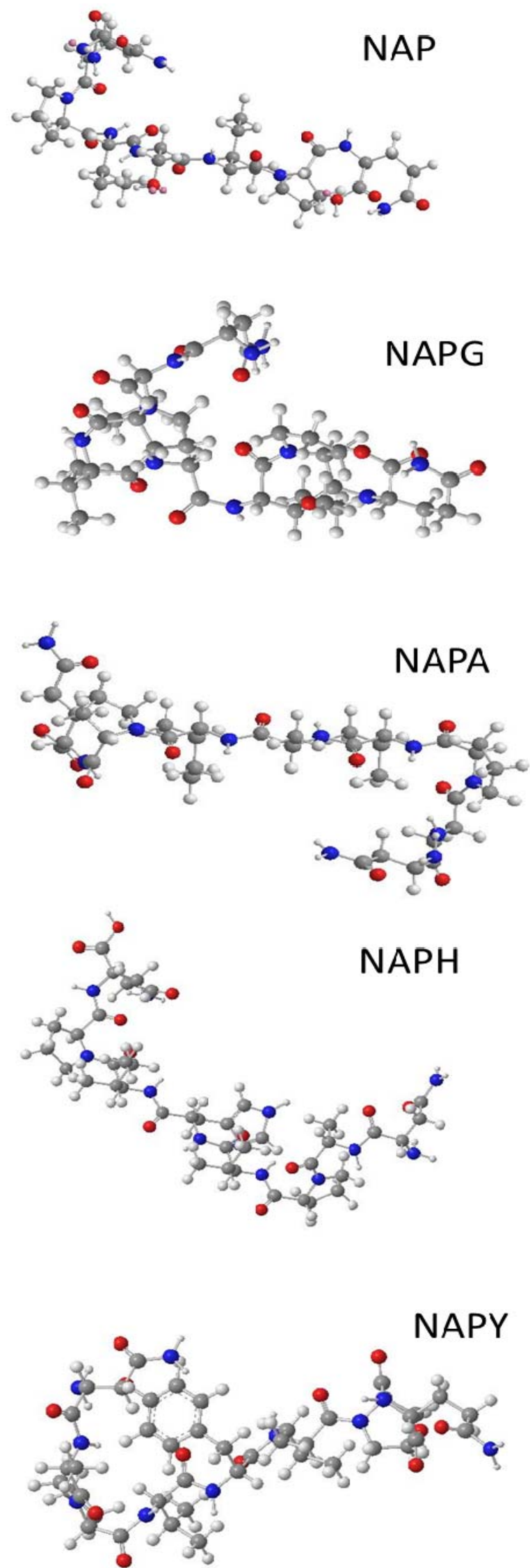

Fig. 5 - Possible spatial structures of the newly synthesized peptides. 


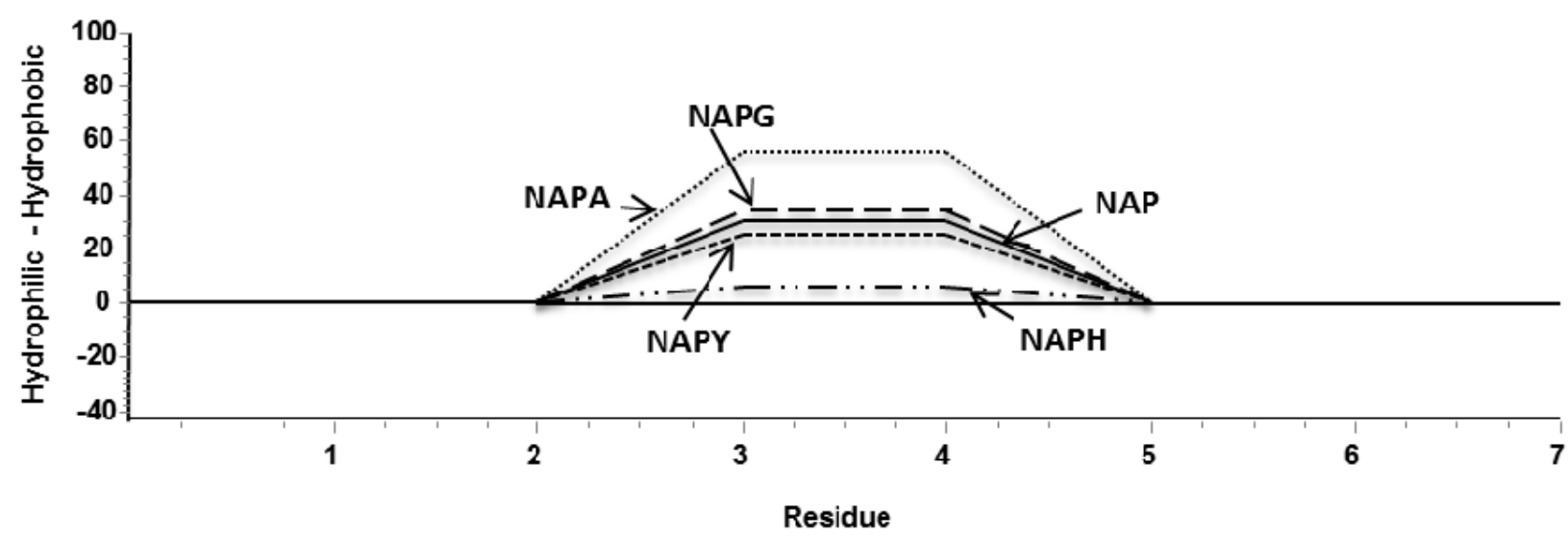

Fig. 6 - Hydrophobicity index for the five peptides as calculated by the GPMAW software.

Thus, the second derivative of the FT-IR spectra of NAP peptides was calculated in the range from 1700 to $1600 \mathrm{~cm}^{-1}$ of amide I band. As shown in Figure 4.b, the second derivative confirmed the presence of alpha-helix conformers in the structure of all peptides. Thus, an intense signal at $1655 \mathrm{~cm}^{-1}$ ( $\alpha$-helix) can be easily noticed both in the NAP and NAPG spectra. The $\alpha$-helix conformation suggested by the peak at $1651 \mathrm{~cm}^{-1}$ was found mostly in NAPY peptide and less in NAPA or NAPH molecules.

The band at 1687-1682 could be assigned either to $\beta$-turn or $\beta$-sheet populations. Since the molecule is small and cannot form $\beta$-sheet structures, the signal was unambiguously assigned to $\beta$-turn conformers. From the intensity of these signals in the second derivative of the spectrum, it is possible to deduce the proportion of the conformers of these molecules. Thus, NAP, NAPG and NAPY peptides are predominantly found as alpha-helix conformers, while NAPA and NAPH are in the ratio of $50 \%$ beta-turn and $50 \%$ alpha helix.

\section{Spatial structure of peptides}

Using Chem3D Ultra 10.0 software, we calculated the space arrangement as well as the energy and chemical bonds distances to find possible structures of the peptides (Fig. 5). Our computer simulation studies showed that the peptides are different one from another. As observed in Figure 5, the peptides displayed predisposition towards torsion structures. Moreover, the FTIR analysis revealed that the peptides structure exhibited a higher tendency for $\alpha$-helical and $\beta$-turn conformation. However, since the peptides are formed only from eight amino acids, their structure is not as stable as that of the large proteins. For instance, they are highly flexible and solvated to a greater extend compared to globular protein.

\section{GPMAW study}

Using the GPMAW program, the MS/MS fragmentation, theoretical mass and $\mathrm{pI}$ (the isoelectric point), absorption, charge, and HPLC elution times of studied peptides can be estimated. The hydrophobicity index of NAP peptide and its mutants, simulated with the GPMAW software, is shown in Figure 6. Although all peptides exhibit hydrophobic properties, their hydrophobicity depends on each structure. Indeed, their hydrophobicity was found closely related to the number of hydrocarbon groups present in their structure. The native NAP peptide contains a predominantly hydrophobic moiety. However, the most hydrophobic was the peptide NAPA $\left({ }^{5} \mathrm{~S} \rightarrow \mathrm{A}\right)$, followed by NAPG $\left({ }^{5} \mathrm{~S} \rightarrow \mathrm{G}\right)$. Both peptides have in their structure a nonpolar amino acid compared to the native peptide, hence it is expected to display a more pronounced hydrophobicity. The peptides modified with histidine and tyrosine displayed a lower hydrophobicity compared to the native peptide, the least hydrophobic being the NAPH peptide. The hydrophilic character of NAPH and NAPY peptides was supposed to be related to the presence of the imidazole moiety of histidine in $\mathrm{NAPH}$ and the phenol $\mathrm{OH}$ group characteristic to tyrosine in NAPY.

\section{EXPERIMENTAL}

\section{Materials}

Peptide synthesis was performed on Fmoc-Gln(Trt)-Wang resin with a binding capacity of $0.4-0.8 \mathrm{mmol}$ amino acid/g of resin (Fig. 1). The amino acids required for synthesis were $\alpha$ - 
amide group protected with Fmoc group (9-fluorenylmethyloxycarbonyl). The Fmoc-amino acids: Fmoc-L-Asn(Trt)-OH, Fmoc-L-Ala-OH, Fmoc-L-Pro-OH, Fmoc-L-Val-OH, FmocL-Ser(tBu)-OH, Fmoc-Gly-OH, Fmoc-His(Trt)-OH, FmocTyr-OH, Fmoc-L-Ile-OH, Fmoc-L-Gln(Trt)-OH, Fmoc-LCys(Trt)-OH were obtained from GL Biochem (Shanghai).

Dichloromethane (DCM) and diethyl ether were purchased from Scharlab S.L. (Barcelona, Spain). Dimethylformamide (DMF) was obtained from Carl Roth $\mathrm{GmbH}$ (Karlsruhe, Germany). Piperidine (PYP), 4-methylmorpholine (NMM), triisopropylsilan (TIS), trifluoroacetic acid (TFA), bromophenol blue, ethanol, acetonitrile (ACN) and the activator HBTU [2-(1H-benzotriazole-1-yl)-1,1,3,3-tetramethyluronium hexafluorophosphate] were achieved from Merck (Germany). $\alpha$-cyano-4-hydroxycinnamic acid matrix (HCCA) was purchased from Sigma-Aldrich (Germany). The solutions were prepared using deionized water $(18.2 \mathrm{M} \Omega \cdot \mathrm{cm})$ from a Milli-Q system (Millipore, Bedford, MA). All reagents were used without further purification.

\section{Instruments}

The obtained peptides were purified using a Dionex UltiMate 3000 UHPLC chromatographic instrument from Thermo Scientific, Breman, Germany. Separation was performed on a Vydac analytical C18 column of $4.6 \mathrm{~mm}$ and a length of $250 \mathrm{~mm}$. Spectrum processing was performed using Chromeleon тм 7.2 Chromatography Data System (CDS). Chromatograms obtained were then adjusted in PowerPoint.

MALDI-ToF MS analysis was performed on a Bruker Ultraflex MALDI ToF/ToF mass spectrometer operated in positive reflectron mode and equipped with a pulsed nitrogen UV laser $\left(\lambda_{\max } 337 \mathrm{~nm}\right)$. The samples were loaded onto a $384-$ spot target plate of the MALDI-ToF instrument using the dried-droplet method: the sample and the matrix solution (2,5dihydroxybenzoic acid) were mixed on the target and allowed to dry in the ambient air. The obtained spectra were processed using Bruker's FlexAnalysis 3.4 software.

FT-IR spectra were recorded with a Bruker Alpha-P FTIR spectrometer (Bruker Optic GmbH, Ettlingen, Germany) equipped with a deuterated triglycine sulphate (DTGS) detector, a temperature-controlled single-bounce diamond attenuated total reflectance (ATR) crystal, and a pressure application device for solid samples. The obtained spectra were processed using the Bruker's OPUS software.

\section{Synthesis of octapeptides}

Manual synthesis of peptides by the solid phase method was performed in a fritted plastic syringe. The installation for synthesis required the connection to a vacuum pump to remove the washing solutions. Peptide synthesis was performed in dimethylformamide (DMF) medium. Protecting groups such as Fmoc or tert-butyl, used to protect the amino acids at the $\mathrm{N}$-terminus or the side chain, were removed with $20 \%$ piperidine in dimethylformamide.

The following five peptides (100 micromoles) were synthesized: $\mathrm{H}_{2} \mathrm{~N}-\mathrm{NAPVSIPQ}-\mathrm{COOH} \quad$ (NAP), $\mathrm{H}_{2} \mathrm{~N}-$ NAPVGIPQ-COOH (NAPG), $\mathrm{H}_{2} \mathrm{~N}-\mathrm{NAPVAIPQ}-\mathrm{CONH}_{2}$ (NAPA), $\mathrm{H}_{2} \mathrm{~N}-\mathrm{NAPVHIPQ}-\mathrm{COOH}$ (NAPH) and $\mathrm{H}_{2} \mathrm{~N}$ NAPVYIPQ-COOH (NAPY), respectively. Peptide synthesis was performed manually from the C-terminus of the peptide to the N-terminus by the Fmoc/tBu Solid Phase Synthesis (SPPS) method. Due to the use of a Fmoc-Gln (Trt) -Wang resin in which the first amino acid is attached to the solid supporter, the obtained peptides exhibit free carboxyl group - $\mathrm{COOH}$ upon the final cleavage.

After weighing $250 \mathrm{mg}$ resin, the theoretical amount to synthesize $100 \mu \mathrm{M}$ peptide, the resin was allowed to swell in the syringe in DMF for $30 \mathrm{~min}$. The first activated amino acid was added after removing the Fmoc protecting groups on the resin with a solution of $20 \%$ piperidine in DMF. The deprotection step requires the successive replacement of the deprotection solution at 2, 2, 5, 10, 2 and 2 minutes, respectively. Washing was carried out 6 times using DMF solution.

Activation of the new amino acid was accomplished by adding $190 \mathrm{mg}$ of HBTU and $110 \mu \mathrm{L}$ of N-methylmorpholine to the amino acid solution dissolved in DMF. The coupling procedure was performed for 50 minutes for each amino acid. This step needs to be repeated twice in other to achieve a highefficiency coupling. The degree of coupling was checked by reaction of resin with blue bromophenol (yellow colorationcomplete coupling, blue coloration-incomplete coupling). Each amino acid in the sequence was subjected to the same wash-deprotection-activation cycle.

Finally, the deprotected peptide was washed 6 times with DMF, 3 times with DCM and 3 times with ethanol, then subjected to lyophilization and weighing. Final cleavage of the peptides from the resin was performed in the dark for 3 hours with a TFA: TIS: $\mathrm{H}_{2} \mathrm{O}$ solution (95: $2.5: 2.5$ ). The amounts used varied according to the yield of the synthesis.

The precipitation of peptides was performed cold $\left(-20^{\circ} \mathrm{C}\right)$ in a solution of ethyl ether left overnight in the freezer. Collection of fractions required the preparation of a filtration plant consisting of a conical filter bottle, a frit funnel and a rubber stopper, the peptide was removed from the filter by successive washings with volumes of $3 \mathrm{~mL}$ of $5 \%$ acetic acid solution. The resulting fractions were collected in Eppendorf vials, lyophilized and weighed. Crude products were characterized by analytical RP-HPLC and MALDI-ToF and if necessary purified by semipreparative RP-HPLC.

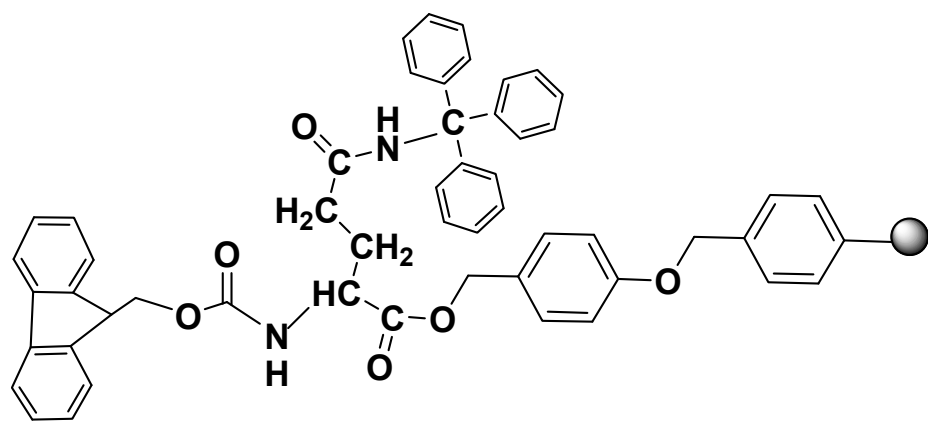

Fig. 7 - Schematic representation of resins Fmoc-GIn(Trt)-Wang Resin used for peptide synthesis. 


\section{Chromatography}

The obtained peptides were purified using a Dionex UltiMate 3000 UHPLC chromatographic instrument from Thermo Scientific, Bremen, Germany. Separation was performed in aqueous-organic medium on a Vydac analytical $\mathrm{C}_{18}$ column of $4.6 \mathrm{~mm}$ and a length of $250 \mathrm{~mm}$. The mobile phase used consisted in an aqueous solution of $0.1 \%$ TFA in redistilled water $(\mathrm{v} / \mathrm{v})$ as solvent $\mathrm{A}$ and $80 \% \mathrm{ACN}, 0.1 \%$ TFA in redistilled water $(\mathrm{v} / \mathrm{v})$ as solvent B. The peptides $(0.1$ $\mathrm{mg} / \mathrm{mL}$ ) were dissolved in solvent A, filtered and automatically injected into the chromatographic system.

The separation was performed at a flow rate of $1 \mathrm{~mL}$ per minute using in the first 2 min a mixture of $5 \% \mathrm{~B}$ and $95 \% \mathrm{~A}$ followed by a short linear gradient of $5 \%$ to $20 \%$ B over the next $3 \mathrm{~min}$ and a longer one (10 $\mathrm{min}$ ) from $20 \%$ to $100 \% \mathrm{~B}$ during which the peptide elution occurs. The UV detector was set at $215 \mathrm{~nm}$, characteristic for the amide bond and the working temperature was set at $25^{\circ} \mathrm{C}$.

\section{MALDI-ToF mass spectrometry}

The Matrix-Assisted Laser Desorption Ionization Time-ofFlight (MALDI-ToF) technique is based on the acceleration of a set of ions to a detector where all the ions received the same amount of energy. ${ }^{32}$ As any mass spectrometer, it consists of three functional units: the nitrogen laser source that pulses in the UV field $(337 \mathrm{~nm})$ and is responsible for the ionization and the transfer of sample ions into the gaseous phase. The mass analyser known as ToF (time of flight) is based on the rate at which the ions pass the distance between the ionization chamber and the detector. Although the ions are accelerated with the same energy, they are separated according to their mass-charge ratio $(\mathrm{m} / \mathrm{z})$. The detector identifies the ions and converts their signals into electrical ones. Mass determination accuracy vary from $0.01 \%$ to $0.1 \%$ depending on the sample preparation technique and the method of choice for calibration. Results were expressed as atomic mass units (Da).

In order to analyse the peptides through the MALDI MS technique, the samples were co-crystallized with an excess of organic matrix capable to absorb at $337 \mathrm{~nm}$ and volatilize under the action of laser radiation. Thus, a saturated solution of $\alpha$-cyano-4-hydroxy-cinnamic acid (HCCA) dissolved in a solution containing 2:1 ACN: 0.1\%TFA in MilliQ was used for peptide mapping. Using the dried drop method, that implies adding first $1 \mu \mathrm{L}$ of sample and over it $1 \mu \mathrm{L}$ of freshly prepared matrix solution, the mixture was deposited on a conductive metallic plate called target and allowed to dry. After co-crystallization, the metal plate was introduced into the mass spectrometer and bombarded with short laser pulses. The desorbed and ionized molecules were accelerated by an electrostatic field and discharged through a high-fly metal flight tube. Depending on their mass, ionized molecules reach the detector at different times, the flight time being in the order of milliseconds. ${ }^{33}$

The spectra were recorded in the positive reflecton mode using the following parameters: $20 \mathrm{kV}$ acceleration voltage, $40 \%$ grid voltage, $140 \mathrm{~ns}$ delay, low mass gate of $500 \mathrm{Da}$ and an acquisition mass range of 600-3500 Da. Into the final mass spectrum were accumulated 300 shots per acquisition.

External calibration was carried out using the monoisotopic masses of singly protonated ion signals of Bradykinin(1-7) (m/z 757.4), Angiotensin II (m/z 1046.5), Angiotensin I (m/z 1296.7), Substance P (m/z 1347.7), Bombesin (m/z 1619.8), Renin Substrate (m/z 1758.9), ACTH clip(1-17) (m/z 2093.1), ACTH clip(18-39) (m/z 2465.2) and Somatostatin(28) (m/z 3147.5).

\section{FT-IR spectroscopy}

Fourier transforms infrared spectroscopy (FT-IR) is an instrumental method used to construct and interpret spectra obtained as a result of some atomic vibration transitions in molecules. This method consists in determining the wavelength and intensity of infrared absorption of electromagnetic radiation by a sample. ${ }^{34}$ The field of infrared radiation represents the part of the electromagnetic spectrum between the field of visible and microwave radiation. Absorption in this area is due to the contact between the electrical component of the incident electromagnetic radiation and the electrical dipoles of the molecules. ${ }^{35}$

Functional groups may be associated with characteristic infrared absorption bands corresponding to the fundamental vibrations of functional groups. A normal vibration mode is active in infrared (it absorbs incident infrared light) if there is a change in the dipole moment of the molecule during the vibration. Thus, symmetrical vibrations are usually not detected in infrared. Instead, asymmetric vibrations of all molecules are detected. This lack of selectivity allows us to investigate the properties of all chemical groups in a single sample, and especially amino acids and water molecules that can hardly be observed by other spectroscopic techniques. Strong infrared absorptions of permanent dipole groups (i.e., polar bonds) are observed. As such, the carbonyl groups of the polypeptide chain contribute greatly to the infrared absorption spectra of the proteins. ${ }^{35}$

Devices used to obtain infrared spectra are called IR spectrophotometers. They use electromagnetic radiation belonging to the infrared range to excite molecules and create vibrational transitions that can then be transposed into the spectrum and associated with a functional group. The obtained spectra are used in the qualitative and structural determinations of organic or inorganic substances.

Attenuated Total Reflection (ATR) is an easy-to-use FTIR sampling method that can provide surface-sensitive analysis and is ideal for both solid and liquid samples. The principals of ATR are based on measuring the modification that appear in the internally reflected IR beam when it comes in contact with the samples. The infrared light is passed through a crystal situated in direct contact with the sample. The diamond crystal is the ideal material for ATR since it can withstand pressure application up to 30000 psi, prevents the possibility of scratching the crystal and is compatible with high and low $\mathrm{pH}$ samples. $^{36}$

The FTIR spectra of the peptides were recorded in solid state on a Bruker Alpha-P FTIR spectrometer (Bruker Optic GmbH, Ettlingen, Germany) equipped with a deuterated triglycine sulphate (DTGS) detector, a temperature-controlled single-bounce diamond attenuated total reflectance (ATR) crystal, and a pressure application device for solid samples. All FTIR spectra were recorded with a spectral resolution better than $2 \mathrm{~cm}^{-1}$, with wavenumber accuracy of $0.01 \mathrm{~cm}^{-1}$. Processing of the FTIR data was performed using Bruker OPUS software.

\section{Computer programs}

For the calculation of exact mass (monoisotopic mass), the application web ChemCalc was used. In addition, the userfriendly web interface of this application allows to predict the isotopic distribution graph and calculate peptide fragmentation. Similar information can be obtained using the General Protein/Mass Analysis for Windows (GPMAW, Lighthouse Data, Denmark) program. Besides, this soft is 
capable to generate the hydrophobicity graph, characteristic to the studied peptide.

The Chem3D Ultra 10.0 software was used because it allows the calculation of the space arrangement, the energy and chemical distances in order to find possible structures of the compounds. All images were processed using PowerPoint.

\section{CONCLUSIONS}

In this study four new NAP-based peptides were designated, synthesized and characterized. The MS spectra of the newly synthesised peptides confirmed the expected sequences while the HPLC method revealed their purity. FT-IR spectra of the eight amino acid peptides afforded some information on their conformation; on analysing the second derivative spectra additional data associated to $\alpha$-helical and $\beta$-turn conformations were acquired. Besides, the spatial structure of peptides performed using Chem3D Ultra 10.0 software revealed a peptide affinity for the torsion structures.

We aim to specifically examine NAP mimetic peptides and their role in preventing the aggregation of amyloid- $\beta$ peptides associated with Alzheimer's disease. Consequently, further studies are required in order to determine the peptide structure, interaction, and function alone or in the presence of metal ions.

Acknowledgements. Funding from the Roumanian Government (UEFISCDI Bucharest, PN-III-P4-ID-PCE-20160376 , contract $56 / 2017$ ) is gratefully acknowledged.

\section{REFERENCES}

1. S. Chandrudu, P. Simerska and I. Toth, Molecules, 2013, 18, 4373-4388.

2. M. C. Paşcanu, E. Bogdan, A. Terec, I. Grosu, and N. D. Hădade, Rev. Roum. Chim., 2017, 62, 349-355.

3. S. Deshayes, M. C. Morris, G. Divita and F. Heitz, Cell. Mol. Life Sci., 2005, 62, 1839-1849.

4. R. Behrendt, P. White and J. Offer, J. Pept. Sci., 2016, 22, 4-27.

5. M. Murariu, E. S. Dragan and G. Drochioiu, Biomacromolecules, 2007, 8, 3836-3841.

6. B.-A. Petre, N. Youhnovski, J. Lukkari, R. Weber and M. Przybylski, Eur. J. Mass Spectrom., 2005, 11, 513-518.

7. C.-I. Ciobanu, R. Stefanescu, M. Niculaua, T. Teslaru, R. Gradinaru and G. Drochioiu, Eur. J. Mass Spectrom., 2016, 22, 97-104.

8. A.-V. Lupaescu, M. Jureschi,C.-I. Ciobanu, L. Ion, G. Zbancioc, B.-A. Petre and G. Drochioiu, Int. J. Pept. Res. Ther. 2018, 1-7.

9. N. Huertas Méndez, Y. Vargas Casanova, A. K. Gómez Chimbi, E. Hernández, A. L. Leal Castro, J. M. Melo Diaz, Z. J. Rivera Monroy and J. E. García Castañeda, Molecules, 2017, 22, 452.
10. Y. Vargas Casanova, J. A. Rodríguez Guerra, Y. A. Umaña Pérez, A. L. Leal Castro, G. Almanzar Reina, J. E. García Castañeda and Z. J. Rivera Monroy, Molecules, 2017, 22, 1641.

11. Y. Javadzadeh and L. Azharshekoufeh Bahari, Nano- and Microscale Drug Delivery Systems, 2017, 131-146.

12. M. Amblard, J.-A. Fehrentz, J. Martinez and G. Subra, Peptide Synthesis and Applications, 2005, 3-24.

13. D. Arneson, Y. Zhang, X. Yang and M. Narayanan, J. Genet., 2018, 97, 795-806.

14. T. K. Karamanos, A. P. Kalverda, G. S. Thompson and S. E. Radford, Prog. Nucl. Magn. Reson. Spectrosc., 2015, 88-89, 86-104.

15. I. Gozes, B. H. Morimoto, J. Tiong, A. Fox, K. Sutherland, D. Dangoor, M. Holser-Cochav, K. Vered, P. Newton, P.S. Aisen, Y. Matsuoka, C. H. van Dyck and L. Thal, CNS Drug Rev., 2006, 11, 353-368.

16. I. Magen and I. Gozes, Neuropeptides, 2013, 47, 489-495.

17. I. Gozes, Curr. Pharm. Des., 2011, 17, 1040-1044.

18. O. Ashur-Fabian, Y. Segal-Ruder, E. Skutelsky, D. E. Brenneman, R. A. Steingart, E. Giladi and I. Gozes, Peptides, 2003, 24, 1413-1423.

19. I. Gozes, A. Stewart, B. Morimoto, A. Fox, K. Sutherland and D. Schmeche, Curr. Alzheimer Res., 2009, 6, 455460.

20. R. R. Leker, A. Teichner, N. Grigoriadis, H. Ovadia, D. E. Brenneman, M. Fridkin, E. Giladi, J. Romano and I. Gozes, Stroke, 2002, 33, 1085-1092.

21. I. Gozes, Y. Schirer, A. Idan-Feldman, M. David and S. Furman-Assaf, J. Mol. Neurosci., 2014, 52, 1-9.

22. S. Oz, O. Kapitansky, Y. Ivashco-Pachima, A. Malishkevich, E. Giladi, N. Skalka, R. Rosin-Arbesfeld, L. Mittelman, O. Segev, J. A. Hirsch and I. Gozes, Mol. Psychiatry, 2014, 19, 1115-1124.

23. I. Gozes, S. Sragovich, Y. Schirer, and A. Idan-Feldman, J. Mol. Neurosci., 2016, 59, 220-231.

24. L. F. Marvin, M. A. Roberts, and L. B. Fay, Clin. Chim. Acta, 2003, 337, 11-21.

25. X. Chen, P. Drogaris, and M. Bern, J. Proteome Res., 2010, 9, 3270-3279.

26. L. Patiny, and A. Borel, J. Chem. Inf. Model., 2013, 53, $1223-1228$.

27. B. Stuart, Kirk-Othmer Encyclopedia of Chemical Technology, 2005, 14.

28. J. Kong and S. Yu, Acta Biochim. Biophys. Sin. (Shanghai)., 2007, 39, 549-559.

29. M. Murariu, L. Ion, and C. Ciobanu, Rev. Roum. Chim., 2017, 62, 277-289.

30. A. Adochitei, and G. Drochioiu, Rev Roum Chim, 2011, 56, 783-791.

31. A. Ouasri, A. Rhandour, M. C. Dhamelincourt, P. Dhamelincourt, and A. Mazzah, Spectrochim. Acta Part A Mol. Biomol. Spectrosc., 2002, 58, 2779-2788.

32. N. Singhal, M. Kumar, P. K. Kanaujia, and J. S. Virdi, Front. Microbiol., 2015, 6 .

33. A. Croxatto, G. Prod'hom, and G. Greub, FEMS Microbiol. Rev., 2012, 36, 380-407.

34. J. Kong and S. Yu, Acta Biochim. Biophys. Sin., 2007, $39,8,549-59$.

35. C. Berthomieu, R. Hienerwadel, Photosynth. Res., 2009, 101, 157-170.

36. V. Freger and A. Ben-David, Anal. Chem., 2005, 77, 18, 6019-6025. 
